\title{
Surveying Volcanic Arcs with Satellite Radar Interferometry: The Central Andes, Kamchatka, and Beyond
}

Matthew E. Pritchard, Department of Geosciences, Princeton University, Princeton, New Jersey 08544, USA

Mark Simons, Seismological Laboratory, Division of Geological and Planetary Sciences, California Institute of Technology, Pasadena, California 91125, USA

\section{ABSTRACT}

Satellite Interferometric Synthetic Aperture Radar (InSAR) permits both synoptic and detailed surveys of magmatic activity in volcanic arcs. To il- lustrate this capability, we summarize here the results of an extended study of inferred magmatic activity in the central Andean arc (Pritchard and Simons, 2002; Pritchard, 2003; Pritchard and Simons,

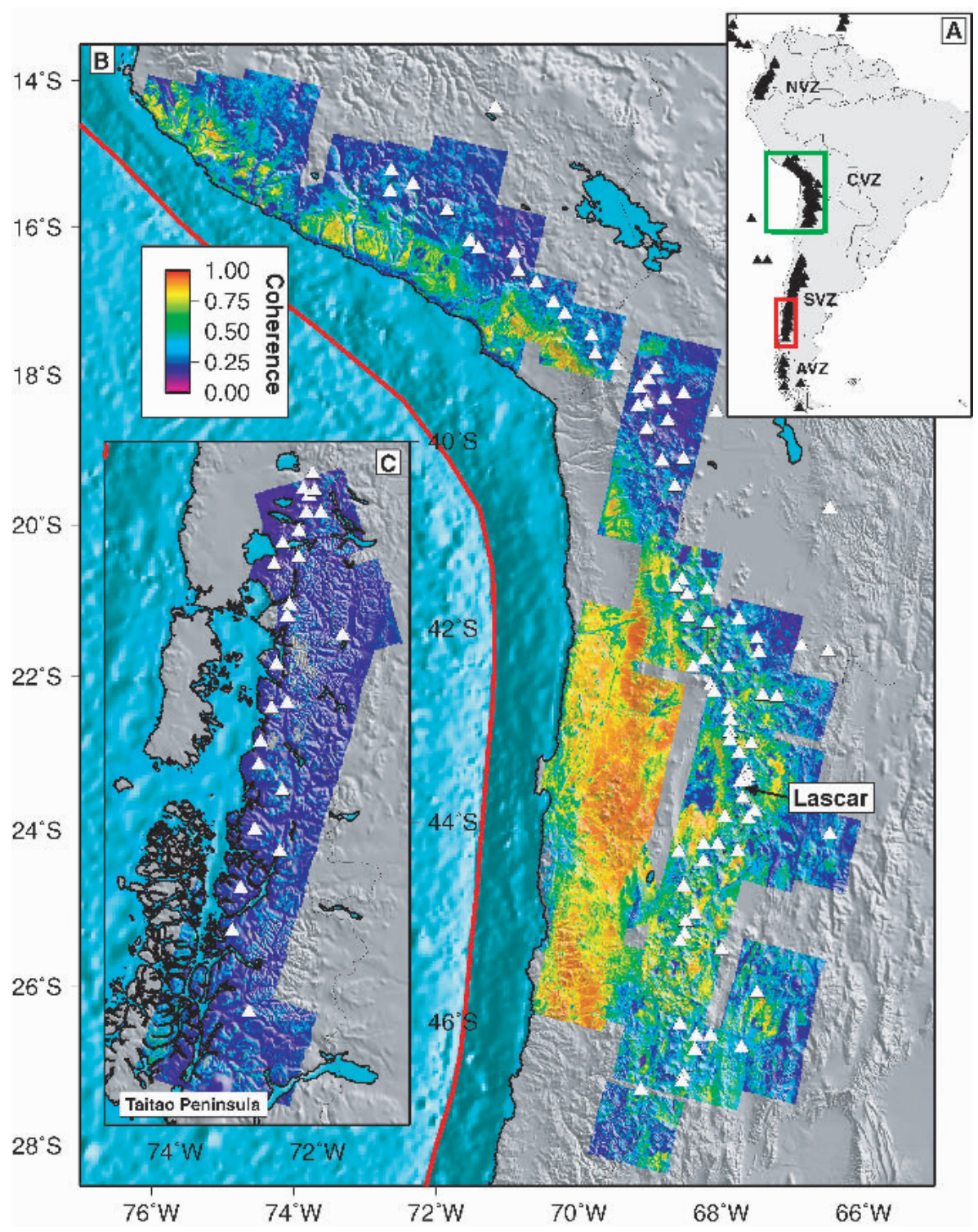

2004), as well as new results from Kamchatka. In the central Andes, encompassing parts of Peru, Bolivia, Chile, and Argentina, we have observed $\sim 900$ volcanoes between 1992 and 2003 and found four previously undocumented sources of deformation. Coupled with surveys in other arcs, this deformation indicates that short-lived pulses of magma movement are common, although the relation of these movements to eruptive activity is unclear. In fact, no co-eruptive deformation was detected from eruptions at four other Andean volcanoes. In Kamchatka, the limits of current InSAR satellites are apparent in terms of the quality of the measurements and coverage of the arc. Nonetheless, we observe subsidence associated with a large lava flow that erupted 28 years ago and inflation of a geothermally active caldera. While a global inventory of volcanic arcs is impossible with current datasets, InSAR is a critical tool for understanding volcanic hazard at most of the world's poorly monitored subaerial volcanoes as well as for searching for large magma reservoirs.

\section{INTRODUCTION}

Volcanoes have different personalities-while some give notice of impend-

Figure 1. Interferometric coherence (a measure of the quality of the Interferometric Synthetic Aperture Radar, or InSAR, measurement) from ERS-1 and $-2(5.7 \mathrm{~cm}$ wavelength) draped over shaded relief for the Andes. (A) Reference map, with the green box showing the area in $B$ and the red box indicating the area in $\mathrm{C}$. Black lines show international borders. (B) The central Andes. Triangles are Holocene volcanoes (Smithsonian Institution, 2004). Even though measurements are taken during different seasons and span several years, coherence is high across the region (for a list of dates and data used, see Pritchard and Simons, 2004). We observe the highest interferometric coherence near the arid coast. (C) Coherence in the southern Andes taken during the austral summer and spanning only a few years. Coherence is regionally low, but high in rocky areas (like the Taitao Peninsula). Coherence is maintained on many lava flows (not resolved at the scale of this image), so that deformation measurements are still possible near many volcanoes. Usable data are only available in the southern portion of the southern arc.

GSA Today; v. 14; no. 8, doi: 10.1130/1052-5173(2004)014<4:SVAWSR>2.0.CO;2 
ing eruption, it is often difficult to decipher what many others will do next. Stratovolcanoes are particularly elusive because they can erupt with little warning after centuries of quiescence. For example, after more than a century of sleep, seismic activity at Mount St. Helens was only detected a few months before eruption (e.g., Dzurisin, 2003).

Satellite-based InSAR is revealing that these periods of apparent repose are not totally free of activity. In this paper, we briefly introduce the InSAR method and summarize what it has revealed about 900 volcanoes in the central Andes and other arcs. We then discuss broader issues raised by the new results: the eruptive cycle at stratovolcanoes, how earthquakes may trigger volcanic unrest, the timescales of magmatic intrusions, and the magma flux into volcanic arcs.

\section{RADAR INTERFEROMETRY}

The InSAR technique has wide application, and depending on the antenna configuration, it can be used to measure topography, ocean currents, ground moisture changes, and surface deformation (from glaciers, earthquakes, volcanoes, etc.), and even to study other planets (see reviews by Massonnet and Feigl, 1998; Rosen et al., 2000). Here, we measure ground deformation using satellites that use synthetic aperture radar (SAR) and overfly the same area at least twice (called repeat-pass Interferometric SAR, or InSAR). We use data from four satellites: ERS-1 and -2 (European), JERS-1 (Japanese), and RADARSAT-1 (Canadian). Even though none of these missions was optimized for InSAR, in some cases the radar data are appropriate for creating images of surface deformation with subcentimeter accuracy spanning hundreds of kilometers with a pixel spacing of order ten meters. Other types of measurements can provide more accurate and frequent deformation observations at a single position (e.g., continuous Global Positioning System stations, tiltmeters, and strainmeters), but InSAR is complementary in that it can measure more of the spatial complexity to help resolve the multiple sources of deformation that frequently occur in volcanic areas (e.g., Masterlark and Lu, 2004).

The differences between the recent SAR satellites illustrate the important parameters for using InSAR to monitor volcanoes (see also Zebker et al., 2000). For more detail, several publications have thoroughly outlined the technical principles of SAR and InSAR (e.g.,
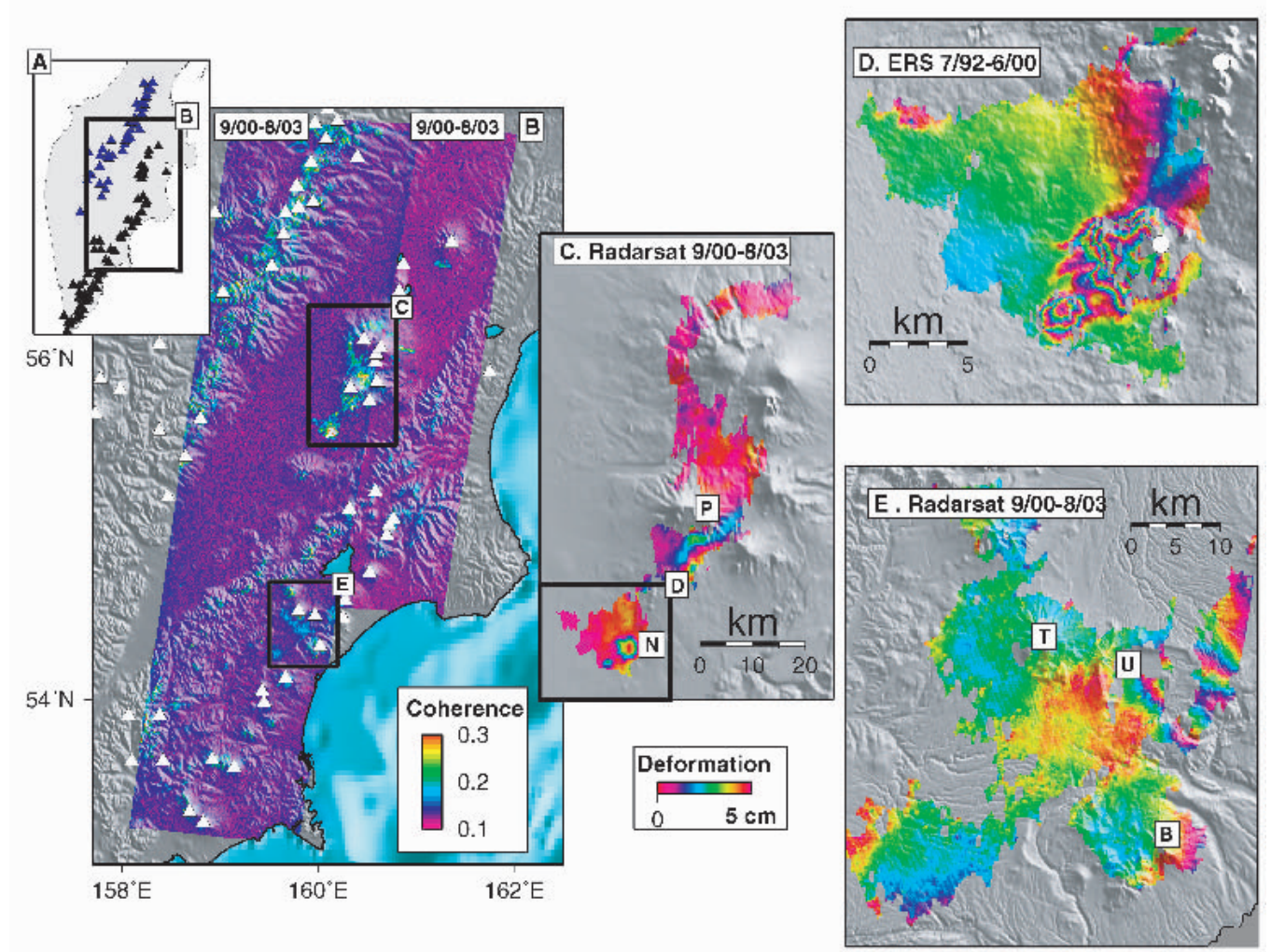

Figure 2. Maps of coherence and deformation from C-band Interferometric Synthetic Aperture Radar (InSAR) in Kamchatka. (A) Reference map showing Holocene volcanoes in Kamchatka (triangles; Smithsonian Institution, 2004). The Sredinny Range volcanoes are in blue and have no historical eruptions (although Ichinsky has fumarolic activity, Fedorov and Shapiro, 1998). The box shows the detail in B. (B) Interferometric coherence from two tracks of RADARSAT-1 data, with the timespan shown above each track. Higher resolution views showing the interferograms are in C and E. (C) Portion of a RADARSAT interferogram spanning 2 September 2000-18 August 2003, around the Kliuchevskoi group (Plosky Tolbachik and New Tolbachik volcanoes are labeled P, N). There is clear subsidence of the New Tolbachik lavas (erupted in 1975-1976), and shown in more detail in D. The fringes south and east of Plosky Tolbachik are likely artifacts (see Figure DR2d. that covers the same time interval). (D) Portion of an ERS interferogram spanning 15 July 1992-17 June 2000 showing subsidence of the New Tolbachik lava flows, where the white circles show approximate eruptive vents (Fedotov and Masurenkov, 1991). (E) Portion of a RADARSAT interferogram spanning 2 September 2000-18 August 2003, showing Taunshits, Uzon, and Bolshoi Semiachik volcanoes (labeled as T, U, and B, respectively). There is possible inflation at Uzon caldera (see GSA Data Repository; see footnote 1). 
Massonnet and Feigl, 1998; Rosen et al., 2000; Bürgmann et al., 2000; Hanssen, 2001).

1. Wavelength: Successful measurement of surface deformation requires the radar-scattering properties of the ground to remain relatively unchanged between observations. In other words, the radar returns must maintain coherence over the time spanned by the two measurements. Coherence depends on the radar wavelength, with longer wavelengths (such as the $24 \mathrm{~cm}$ of JERS- 1 compared to the $5.7 \mathrm{~cm}$ of ERS- 1 and -2 and RADARSAT1) providing higher coherence than shorter wavelengths over the same time interval because they are less sensitive to fine-scale movements of surface scatterers (leaves, pebbles, etc.; Zebker and Villasenor, 1992; Rosen et al., 1996). We have created maps of the radar interferometric coherence at $5.7 \mathrm{~cm}$ over parts of the Andes and Kamchatka (Figs. 1 and 2). As long as snow-free images are compared, coherence should be high in regions that have little precipitation and vegetation. Therefore, coherence is high along the arid coast of the central Andes, but low in the mountains. Coherence is low in all of the southern Andes and Kamchatka because of the wetter climate than the central Andes. Nonetheless, deformation can still be detected in the southern Andes and Kamchatka (discussed below), because measurements are possible on lava flows and rocky outcrops.

2. Data Availability: We need frequent global coverage to capture the time-dependence of ground deformation. At best, current satellite missions can provide data on a monthly basis. But in reality, usable data are rarely acquired in many volcanic arcs (see point 3). By using multiple satellites we can increase the spatial and temporal coverage, but with existing data, a global survey of all active subaerial volcanoes is impossible. A single radar scene typically costs \$100s-\$1000s (depending on the satellite), so that even our incomplete survey of the central Andes including 300 scenes, is costly, albeit dramatically cheaper than making comparable groundbased measurements.

3. Orbit Control: Usable data are rarely acquired during each satellite overpass because at least two requirements must be satisfied: the SAR data must be from the summer (to avoid snow-not a real problem in the central Andes, but a serious issue in many other places); and the two satellite flyovers must be in almost the same location (i.e., the interferometric baseline between the images must be small). Each satellite has

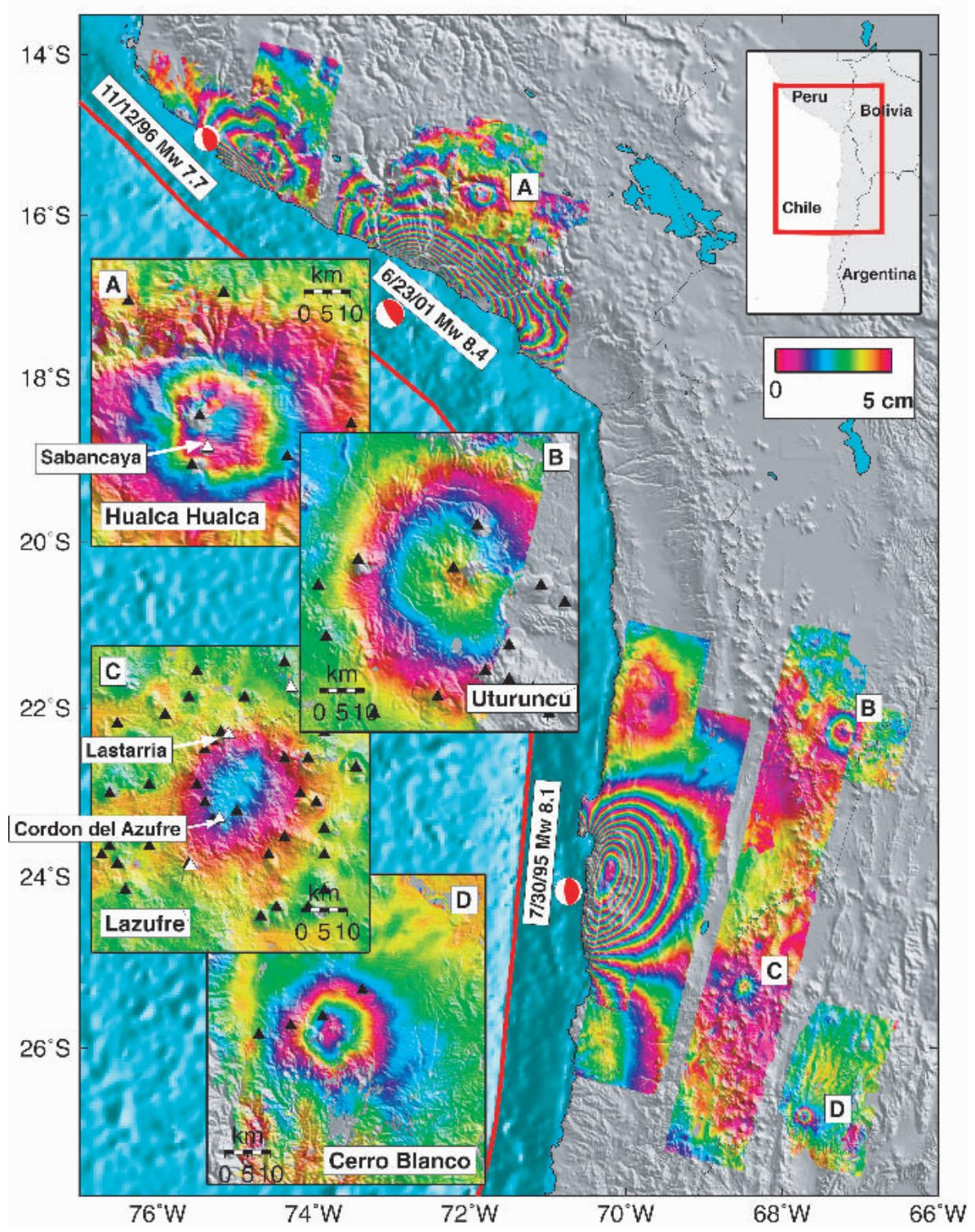

Figure 3. Color contours of ground deformation draped over shaded relief from three subduction zone earthquakes along the coast and four volcanic centers (for more details, see Pritchard et al., 2002; Pritchard and Simons, 2002; Pritchard, 2003). Black lines show international borders. Each contour corresponds to $5 \mathrm{~cm}$ of deformation in the radar line-ofsight direction. Inset maps show higher resolution interferograms at the four centers of active deformation, showing the relation of the center of deformation to the location of local edifices (potentially active volcanoes in white, all others in black, as classified by de Silva and Francis, 1991). Reference map in upper right corner places study area in regional context. Deformation from Hualca Hualca was not contemporaneous with the $2001 M_{w} 8.4$ earthquake, so separate interferograms are shown there. 
a different ability to achieve a small baseline between observations, and this ability can change during a satellite's lifetime.

4. Observing Geometry: InSAR only measures deformation in the line-of-sight (LOS) of the radar beam, implying that only one component of the deformation field can be measured in an individual interferogram.

Multiple satellite passes with different observation geometries can be used to recover more than one component of deformation, which is important for constraining physical models of the deformation (Dieterich and Decker, 1975). For ERS-1 and -2, the satellites measure mostly vertical deformation, while the JERS-1 recovers equal parts of the horizontal and vertical deformation, and RADARSAT-1 has multiple viewing configurations.

The principal source of coherent noise for all satellite InSAR measurements of ground deformation is atmospheric and can cause errors of several centimeters (e.g., Beauducel et al., 2000). While in certain well-instrumented areas, independent data can constrain the atmospheric artifacts (e.g., Hanssen, 2001), the most globally practical method (and used in our studies) is to use multiple overlapping observations to better characterize the signal and the noise (e.g., Massonnet and Feigl, 1998).

\section{THE CENTRAL ANDES}

In the arid central Andes (Fig. 1), volcanoes are well-preserved; de Silva and Francis (1991) estimate 1113 volcanic structures younger than $20 \mathrm{Ma}$, although only 44 are classified as potentially active (with eruptions younger than the last glaciation; de Silva and Francis [1991]). We place constraints on the deformation at all of the potentially active volcanoes and 945 total volcanic structures between 1992 and 2003 with an accuracy of 1-2 cm (documented in Pritchard and Simons, 2002; Pritchard, 2003; Pritchard and Simons, 2004). We found broad (10s of km), roughly axisymmetric, centimeter-scale deformation at four centers with no previously documented deformation (Fig. 3). Because of low coherence on the edi- fices and the resolution of current digital elevation models, our survey is not very sensitive to deformation within the summit craters (which have diameters less than $\sim 1 \mathrm{~km}$ for much of this arc).

During the period of our survey, two stratovolcanoes were inflating (Uturuncu, Bolivia, and Hualca Hualca, Peru), as was another source between Lastarria and Cordon del Azufre on the border between Chile and Argentina. This third source of inflation is not associated with a volcanic edifice (which will hereafter be called Lazufre). We also found a subsiding caldera, Cerro Blanco, (also called Robledo) in northwest Argentina. None of these deformation sources were listed as active volcanoes, although Hualca Hualca, Peru, and Lazufre could be related to potentially active volcanoes located within $10 \mathrm{~km}$ of the inferred source locations.

We assume that the observed deformation is caused by changes in pressure at depth due to the injection or withdrawal of magma or hydrothermal fluids and/or expansion and contraction caused by temperature or phase changes. Many different models have been considered to explain geodetic observations in volcanic areas (e.g., Dieterich and Decker, 1975; Fialko et al., 2001). Because many of these models can fit the data, we consider a suite of models to constrain the depth and volume change in the reservoir. For example, the inferred source depth is affected by the (unknown) shape of the subsurface reservoir, while variations in the seismic velocity structure appear to have secondary importance (Pritchard and Simons, 2004). Best fitting source depths (below sea level) are as follows: 8-18 km at Hualca Hualca; 12-25 km for Uturuncu; 5-13 km for the Lazufre, and $5-10 \mathrm{~km}$ at Cerro Blanco (Pritchard and Simons, 2004). Because hydrothermal systems are usually $<10 \mathrm{~km}$ deep (e.g., Newhall and Dzurisin, 1988), we suspect that deformation at Uturuncu, Lazufre, and Hualca Hualca has a magmatic origin, and that subsidence at Cerro Blanco is at least augmented by hydrothermal activity. Uturuncu lies within a region of low seismic velocity and inferred partial melt (Chmielowski et al., 1999), part of the AltiplanoPuna Magmatic Complex (de Silva and Francis, 1991).
Using InSAR deformation data and some assumptions about the source model, we can place limits on the temporal evolution of inflation (see Figs. 9 and 10 in Pritchard and Simons, 2004). Deformation at all four sources is time dependent, and while these variations in deformation might represent normal intrinsic fluctuations, some of the changes could be induced by external processes. The changes in activity at Uturuncu and Lazufre may have been triggered by a $\mathrm{M}_{\mathrm{w}} 7.1$ subduction zone earthquake in 1998. Such remote triggering of deformation in volcanic areas has been observed before, with a variety of mechanisms proposed (e.g., Johnston et al., 1995). Inflation at Hualca Hualca stopped in 1997 , perhaps induced by a large eruption of nearby Sabancaya volcano in May 1997, although there is no obvious relation between the rate of deformation and the eruptions of Sabancaya (Pritchard and Simons, 2004).

We do not observe any deformation associated with eruptions of Lascar, Chile, (the most active volcano in the arc), eruptions at 3 other volcanoes, or 13 other volcanoes that have recent fumarolic activity (Pritchard and Simons, 2004). Other recent studies indicate many primarily basaltic eruptions (smaller than the April 1993 Lascar eruption) in Alaska and at ocean islands that exhibit no observed subsidence (for a complete list, see Pritchard and Simons, 2004).

Yet, the lack of subsidence observed for the April 1993 eruption of Lascar is enigmatic because of the size of the eruption (0.1-0.4 $\mathrm{km}^{3}$ of material, e.g., Smithsonian Institution, 2004). We can rule out injection or withdrawal of magma from a shallow magma chamber, unless the magma chamber can gain or lose magma without deforming, a process that is difficult to imagine for the silicic magmas at Lascar. Modeling indicates that the magma chamber would need to be at least $25 \mathrm{~km}$ deep (possibly much deeper) to explain the lack of deformation from the April 1993 eruption, and such a deep magma chamber might not be consistent with the fact that movements of the lava dome seem to trigger eruptions in at least 1986-1993 (Matthews et al., 1997). Considering the long periods between observations (see Pritchard and Simons, 2004), inflation 


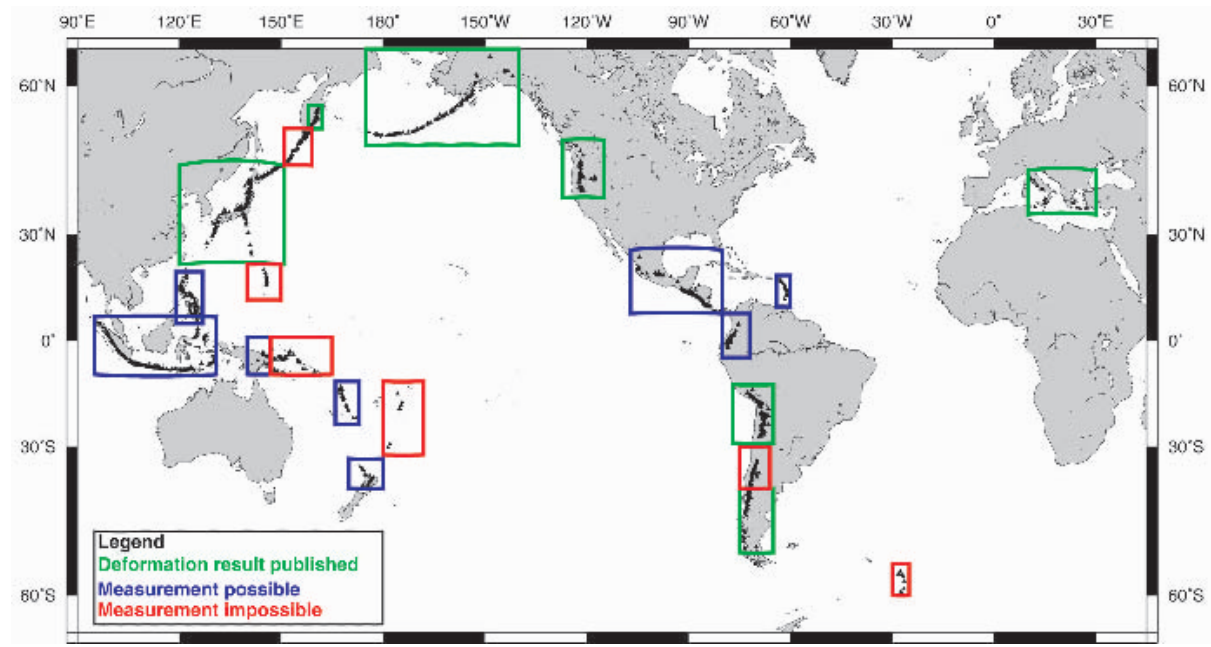

and deflation could nearly exactly cancel each other, especially if the eruptive process is cyclic or the magma chamber quickly repressurizes. In order to resolve whether the Lascar chamber is deep or quickly repressurizes, petrological and seismic studies of the magma chamber location should be undertaken, and InSAR measurements with greater temporal resolution must be acquired.

\section{ERUPTIVE HAZARD}

Inflation at supposedly inactive volcanoes has been found in the Galapagos, Alaska, and the Cascades, and as in the central Andes, is assumed to be of magmatic origin (Lu et al., 2002a; Wicks et al., 2002; Lu et al., 2000a; Amelung et al., 2000). The hazard from these presumed magma intrusions is unclear: will this magma accumulation result in an eruption, or is this a benign intrusion? In this respect, the inferred source at Lazufre is especially enigmatic. It may be related to one of the nearby (within $10 \mathrm{~km}$ ) potentially active volcanoes, a randomly located intrusion, or perhaps the birth of a new volcano or caldera. Assessing hazard is difficult without ancillary information about the eruptive history of the volcano, the subsurface magmatic plumbing (as inferred from seismic tomography or geochemical studies), or current unrest (seismicity, thermal activity, or degassing).

However, observations of deformation can provide some clues to the physical processes occurring at depth and to the potential hazard. For example, there is evidence that the intrusive episodes at dormant volcanoes are short-lived and therefore may commonly occur without eruption. A short timescale for these intrusions is consistent with the fact that deformation at Mount Peulik, Alaska, is inferred to have occurred between 1996 and 1998 (Lu et al., 2002a), and the beginning or ending of periods of deformation was seen at South Sister in Oregon and Hualca Hualca and Lazufre in the central Andes. Geochemical evidence at other volcanoes suggests multiple timescales for intrusions, and that there might be several small intrusions spanning the decades to centuries before an eruption (e.g., Zellmer et al., 2003), so that any eruption might be many years from now.

The durations of intrusive episodes can be governed by a combination of magma supply, the physics of transport, and potentially some external mechanism like earthquakes. We mentioned earlier that a $M_{w} 7.1$ subduction zone earthquake could have affected volcanic deformation in the central Andes, but $M_{w} 8.1$ and $M_{w} 8.4$ earthquakes had no obvious effects (although the $\mathrm{M}_{\mathrm{w}} 8.4$ earthquake may have affected shallow groundwater flow; Pritchard, 2003). A correlation between earthquakes and eruptions is suggested (e.g., Linde and Sacks, 1998), but with InSAR monitoring of volcanic arcs, we can look for the influence of earthquakes on more subtle changes in deformation rates.

Further allaying concerns about an immediate eruptive threat is the paucity of shallow seismicity that may indicate that magma is approaching the surface
Figure 4. Interferometric Synthetic Aperture Radar (InSAR) data availability for volcanic arcs from ERS-1 and -2, JERS and RADARSAT as of March 2004. For the blue boxes, at least one interferogram has been published from the arc (e.g., Zebker et al., 2000), or more than five years of temporal coverage of the arc is possible with one or more interferograms. For the red boxes, coverage is considered incomplete if less than 5 years can be spanned by interferograms (for some arcs, no interferograms can be made). Deformation has been measured in the Japan-Izu-Bonin arc (e.g., Nishimura et al., 2001; Furuya, 2004), the Mediterranean (e.g., Massonnet et al., 1995; Lanari et al., 1998), and the USA (Cascadia and Alaska/Aleutians; e.g., Wicks et al., 2002; Lu et al., 2003a), and studies of all volcanoes in these arcs is ongoing.

at Mount Peulik, Alaska, South Sister, Oregon, or Westdahl, Alaska (e.g., Dixon et al., 2002, http://www.geophys. washington.edu/SEIS/PNSN/SISTERS/). However, an earthquake swarm did occur at South Sister in March 2004. At Uturuncu, Bolivia, a short deployment of a single seismometer revealed a surprisingly high rate of seismicity, but further work is necessary to determine if this is related to magmatic or hydrothermal activity (McNutt and Pritchard, 2003).

While the duration of inflation could provide some clues to the hazard, it is less clear if the horizontal position of the source (e.g., location relative to the edifice) is important in assessing the origin or threat of the deformation. While one might assume that a source of deformation at some distance from an eruptive vent may be a noneruptive intrusion, several eruptions seem to have been fed by magma chambers $5-10 \mathrm{~km}$ away from the eruptive center (Curtis, 1968; Lu et al., 2000c).

To better characterize the eruptive hazard from the magmatic intrusions imaged with InSAR, we need a more complete understanding of the eruptive cycle of each stratovolcano. At some volcanoes (particularly basaltic volcanoes in Hawaii, Alaska, and Iceland) the eruptive cycle seems straightforward: magma enters a chamber, an eruption occurs, the chamber empties, and the chamber refills (e.g., Dvorak and Dzurisin, 1997; Mann et al., 2002; Lu et al., 2003b). At many stratovolcanoes, the pattern is more complicated. Magma may not refill every chamber before 
or after eruption, or might not even be stored in a shallow chamber before erupting (Dzurisin, 2003). If InSAR measurements are made frequently enough so that pre-eruptive, co-eruptive and posteruptive processes can be separated, we can test where and when the simple eruptive cycle works. Groundbased sensors (particularly gravimeters and continuous geodetic stations) will be an important complement to InSAR, especially in cases where magma movements are undetectable by satellite (because the magma moves without deforming the surface or the deformation is too small).

\section{INTER-ARC COMPARISON}

In the central Andes, the deforming volcanoes are not erupting, and we do not observe deformation at the erupting volcanoes. Only four volcanoes out of the hundreds surveyed are deforming, and none of them are the usual suspects of potentially active volcanoes. To explore how representative these results are, we searched the literature and data archives of ERS-1 and -2, JERS, and RADARSAT to determine which other arcs could be surveyed in a similar comprehensive manner (Fig. 4).

A comparison between the central Andes and the Aleutian arc is illustrative of inter-arc variations, because although both have about the same number of Holocene volcanoes (70-80, Smithsonian Institution, 2004), the Aleutian arc has more historic eruptions (41 compared to 17; Smithsonian Institution, 2004), and more actively deforming volcanoes ( 9 compared to 4 , Lu et al., 1997, 2000a, 2000b, 2000c, 2002a, 2002b, 2002c; Mann and Freymueller, 2003; Masterlark and Lu, 2004). The estimated magma flux into both arcs is similar over the long term (e.g., 10 Ma; Karig and Kay, 1981; Francis and Hawkesworth, 1994), although there are within-arc variations (e.g., Fournelle et al., 1994). Short-term temporal variations in the flux are likely (e.g., Fournelle et al., 1994), but at least over the past 10 years, the observed rates of magma intrusion are also similar between arcs, based on incomplete InSAR surveys of both arcs, (summing results from Lu et al., 1997-2003, and Pritchard and Simons, 2004). Of course, the ratio of the volume of material erupted to the volume intruded could vary between arcs, and documenting how this ratio changes in different arcs and tectonic regimes is a goal for future InSAR satellites. Although it is possible that convergence rate controls overall magma flux, other factors also seem to be important, and there is currently no consensus (e.g., Karig and Kay, 1981; Simkin and Siebert, 1984).

For some arcs, we find InSAR data coverage is greater than what has been published, while for other arcs, usable data has not been acquired, or has been acquired for only part of the arc (Fig. 4). For example, in the Kamchatka-Kuril arc, viable data only exists south of Urup island and north of Petropavlovsk, because of the location of downlink stations.

In Figure 2, we present ERS-1 and -2 and RADARSAT data for northern Kamchatka between 1992 and 2003, although most volcanoes are only covered during the last three years (for a complete list, see GSA Data Repository ${ }^{1}$ ). Despite difficulties with coherence and poor knowledge of the orbital baselines, we observe two sources of deformation (Fig. 2). There is one area of subsidence (maximum of $\sim 2.5 \mathrm{~cm} / \mathrm{yr}$ LOS) associated with the basaltic lava flows from the great Tolbachik fissure eruption of 1975-1976 ( 2 km³ ; e.g., Fedotov and Masurenkov, 1991). Subsidence of lava flows and other eruptive products observed elsewhere has been related to thermal contraction, relaxation of the underlying substrate, and closing of pore space (e.g., Lu et al., 2003a).

We also observe inflation (maximum of $\sim 1.5 \mathrm{~cm} / \mathrm{yr}$ LOS; Fig. 2) associated with the geothermally active Uzon caldera (e.g., Belousov et al., 1984). The deformation at Uzon is less certain because of the lower coherence in the area and the existence of only a few measurements (making it harder to rule out atmospheric contamination). A magma body has been inferred below the caldera at $5 \mathrm{~km}$ (Waltham, 2001), and our best fitting model sources lie at this depth or shallower (see GSA Data
Repository). It is difficult to determine if the movement of magmatic or hydrothermal fluids are the cause with only deformation data (e.g., Battaglia et al., 1999). We do not observe deformation associated with eruptions that occurred during the time period of observation at Kliuchevskoi, Sheveluch, or Bezymianny volcanoes, but because of the poor spatial and temporal coverage, only large signals would be detectable (see GSA Data Repository). These preliminary results confirm the diversity of sources of deformation in arcs and the need for synoptic surveys instead of point measurements.

\section{THE FUTURE}

Even though existing InSAR systems have provided new insights into volcanoes and other fields of geophysics, considering the practical difficulties mentioned above, a satellite dedicated and optimized for InSAR could discover much more, and should be a high priority for U.S. funding agencies (National Aeronautics and Space Administration, National Science Foundation, and the U.S. Geological Survey; e.g., Solomon et al., 2003). Key mission characteristics include:

- L-band (24 cm wavelength) radar to maximize interferometric coherence in nonarid environments and over extended time periods in all environments.

- Left and right looking radar from both ascending and descending orbits to provide constraints on the full three-dimensional deformation field.

- Subweekly access to the whole globe to assess time-dependent deformation, generate sufficient observations for stacking, and permit a global inventory of subaerial volcanoes.

- A free and open data policy to maximize innovative use of the data and continued algorithmic improvements.

- Tight orbital control to minimize interferometric baseline, thereby maximizing the number of allowable interferometric pairs and minimizing the sensitivity to topography.

- Accurate a posteori orbital knowledge to provide the most accurate

${ }^{1}$ GSA Data Repository Item 2004139, Tables DR1 and DR2 and Figures DR1-DR3, is available on request from Documents Secretary, GSA, P.O. Box 9140, Boulder, CO 80301-9140, USA, editing@geosociety.org, or at www.geosociety.org/pubs/ft2004.htm. 
estimates of deformation possible.

- Large bandwidth to permit estimation and correction of ionospheric effects.

Such a satellite or constellation of satellites would allow for global volcano monitoring, and would undoubtedly discover unsuspected sources of deformation at many presumably dormant volcanoes and elsewhere. Field surveys could then be targeted at these few volcanoes to assess the threat of eruption. Even at well-monitored volcanoes, InSAR observations are useful because they can measure more of the deformation field, helping to resolve ambiguities about the multiple sources of deformation (flank instabilities, dike intrusions, magma chamber, and hydrothermal system dynamics) in volcanic areas. Such a global compilation of the types of deformation that occur and the relationship with other types of activity (including eruptions) would be invaluable for beginning to decipher how hazardous any particular volcano could be.

Furthermore, a dedicated InSAR satellite would be able to acquire enough radar images so that the data could be stacked together to reduce noise. This technique has already allowed for the detection of deformation of only a few $\mathrm{mm} / \mathrm{yr}$ from the Socorro magma body, New Mexico, at a depth of $\sim 19 \mathrm{~km}$ (Fialko and Simons, 2001). Stacking not only allows for the detection of smaller amplitude deformation at volcanoes, but will reveal deep magma reservoirs and place constraints on the magma flux into these arcs. Over the lifetime of several satellites, we will be able to monitor temporal variations of the magma flux, compare the flux with the geologic average, and compare fluxes between arcs, with implications for understanding the long-term evolution of volcanic arcs and continental growth.

\section{ACKNOWLEDGMENTS}

We are grateful for the comments of Science Editor K. Howard and reviewers D. Dzurisin, S. Jonsson, S. McNutt, and Z. Lu. ERS SAR imagery was acquired under a Category 1 research project from the European Space Agency and was processed with the Caltech/JPL ROI PAC software (Rosen et al., 2004). RADARSAT and some ERS SAR data were provided by the Alaska SAR facil- ity, and we thank E. Fielding, E. Price, and V. Wolf for helping us find and process this data. Digital Elevation Models from the Shuttle Radar Topography Mission at $90 \mathrm{~m}$ per pixel resolution were supplied courtesy of NASA. The GMT program was used to create several figures (Wessel and Smith, 1998). Pritchard was partly supported by a Hess Fellowship from Princeton University. Contribution number 9073 of the Division of Geological and Planetary Science, Seismological Laboratory, California Institute of Technology.

\section{REFERENCES CITED}

Amelung, F., Jonsson, S., Zebker, H., and Segall, P., 2000, Widespread uplift and 'trapdoor' faulting on Galapagos volcanoes observed with radar interferometry: Nature, v. 407, p. 993-996, doi: 10.1038/35039604.

Battaglia, M., Roberts, C., and Segall, P., 1999, Magma intrusion beneath Long Valley caldera confirmed by tempora changes in gravity: Science, v. 285, p. 2119-2122, doi: 10.1126/SCIENCE.285.5436.2119.

Beauducel, B., Briole, P., and Foger, J.-L., 2000, Volcanowide fringes in ERS synthetic aperture radar interferograms of Etna (1992-1998): Deformation or tropospheric effect?: Journal of Geophysical Research, v. 105, p. 16,391-16,402, doi: 10.1029/2000JB900095.

Belousov, V.I., Grib, E.N., and Leonov, V.L., 1984, The geological setting of the hydrothermal systems in the Geysers Valley and Uzon caldera: Volcanology and seismology, v. 5, p. 67-81.

Bürgmann, R., Rosen, P.A., and Fielding, E.J., 2000, Synthetic aperture radar interferometry to measure Earth's surface topography and its deformation: Annual Reviews of Earth and Planetary Science, v. 28, p. 169-209, doi: 10.1146/ANNUREV.EARTH.28.1.169.

Chmielowski, J., Zandt, G., and Haberland, C., 1999, The central Andean Altiplano-Puna Magma Body: Geophysical Research Letters, v. 26, p. 783-786, doi: 10.1029/ 1999GL900078.

Curtis, G.H., 1968, The stratigraphy of the ejecta of the 1912 eruption of Mount Katmai and Novarupta, Alaska, in Coats, R.R., Hay, R.L., and Anderson, C.A., eds., Studies in volcanology, a memoir in honor of Howell Williams: Geological Society of America Memoir 116, p. 153-210.

de Silva, S.L., and Francis, P.W., 1991, Volcanoes of the central Andes: New York, Springer-Verlag, 216 p.

Dieterich, J., and Decker, R., 1975, Finite element modeling of surface deformation associated with volcanism: Journal of Geophysical Research, v. 80, p. 4094-4102.

Dixon, J.P., Stihler, S., Power, J., Tytgat, G., Estes, S., Moran S., Paskievitch, J., and McNutt, S., 2002, Catalog of earthquake hypocenters at Alaskan volcanoes: January 1, 2000 through December 31, 2001: USGS Open File Report 02342, p. 56.

Dvorak, J.J., and Dzurisin, D., 1997, Volcano geodesy: The search for magma reservoirs and the formation of eruptive vents: Reviews of Geophysics, v. 35, p. 343-384, doi: 10.1029/97RG00070.

Dzurisin, D., 2003, A comprehensive approach to monitoring volcano deformation as a window on the eruption cycle: Reviews of Geophysics, v. 41, doi: 10.1029/ 2001RG000107.

Fedorov, P.I., and Shapiro, M.N., 1998, Neogene volcanics of the Kamchatka isthmus and geodynamics of the AleutianKamchatka junction: Geotectonics, v. 32, p. 122-137.

Fedotov, S.A., and Masurenkov, Y.P., editors, 1991, Active volcanoes of Kamchatka: Moscow, Nauka Publishers, $302 \mathrm{p}$.

Fialko, Y., and Simons, M., 2001, Evidence for on-going inflation of the Socorro magma body, New Mexico, from interferometric synthetic aperture radar imaging: Geophysical
Research Letters, v. 28, p. 3549-3552, doi: 10.1029/ $2001 \mathrm{GL} 013318$.

Fialko, Y., Khazan, Y., and Simons, M., 2001, Deformation due to a pressurized horizontal circular crack in an elastic half-space, with applications to volcano geodesy: Geophysical Journal International, v. 146, p. 181-190, doi: 10.1046/J.1365-246X.2001.00452.X.

Fournelle, J.H., Marsh, B.D., and Meyers, J.D., 1994, Age, character, and significance of Aleutian arc volcanism, in Plafker, G., and Berg, H.C., eds., The Geology of Alaska: Boulder, Colorado, Geological Society of America, The Geology of North America, v. G-1, p. 723-757.

Francis, P.W., and Hawkesworth, C.J., 1994, Late Cenozoic rates of magmatic activity in the central Andes and their relationships to continental crust formation and thickening: Journal of the Geological Society [London], v. 151, p. $845-854$.

Furuya, M., 2004, Localized deformation at Miyakejima volcano based on JERS-1 radar interferometry: 1992-1998: Geophysical Research Letters, v. 31, doi: 10.1029/ 2003GL019364.

Hanssen, R.A., 2001, Radar interferometry: Data interpretation and error analysis: Dordrecht, The Netherlands, Kluwer Academic Publishers, $328 \mathrm{p}$.

Johnston, M.J.S., Hill, D.P., Linde, A.T., Langbein, J., and Bilham, R. 1995, Transient deformation during triggered seismicity from the 28 June $M_{w}=7.3$ Landers earthquake at Long-Valley caldera, California: Bulletin of the Seismological Society of America, v. 85, p. 787-795.

Karig, D.E., and Kay, R.W., 1981, Fate of sediments on the descending plate at convergent margins: Philosophical Transactions of the Royal Society of London, Series A, Mathematical and Physical Sciences, v. 301, p. 233-251.

Lanari, R., Lundgren, P., and Sansosti, E., 1998, Dynamic deformation of Etna volcano observed by satellite radar interferometry: Geophysical Research Letters, v. 25, p. 1541 1544, doi: 10.1029/98GL00642.

Linde, A.T., and Sacks, I.S., 1998, Triggering of volcanic eruptions: Nature, v. 395, p. 888-890, doi: 10.1038/27650. Lu, Z., Fatland, R., Wyss, M., Li, S., Eichelberger, J., Dean, K., and Freymueller, J., 1997, Deformation of New Trident volcano measured by ERS-1 SAR interferometry, Katmai National Park, Alaska: Geophysical Research Letters, v. 24, p. 695-698, doi: 10.1029/97GL00539.

Lu, Z., Wicks, J.C., Dzurisin, D., Thatcher, W., Freymueller, J.T., McNutt, S.R., and Mann, D., 2000a, Aseismic inflation of Westdahl volcano, Alaska, revealed by satellite radar interferometry: Geophysical Research Letters, v. 27 p. 1567-1570, doi: 10.1029/1999GL011283.

Lu, Z., Wicks, J.C., Power, J., and Dzurisin, D., 2000b, Deformation of Akutan volcano, Alaska, revealed by satellite radar interferometry: Journal of Geophysical Research, v. 105, p. 21,483-21,496, doi: 10.1029/2000JB900200.

Lu, Z., Mann, D., Freymueller, J., and Meyer, D., 2000c, Synthetic aperture radar interferometry of Okmok volcano, Alaska: Radar observations: Journal of Geophysical Research, v. 105, p. 10,791-10,806, doi: 10.1029/ 2000JB900034.

Lu, Z Wicks, J.C., Dzurisin, D., Power, J.A , Moran, S.C., and Thatcher, W., 2002a, Magmatic inflation at a dormant stratovolcano: 1996-1998 activity at Mount Peulik volcano, Alaska, revealed by satellite radar interferometry: Journal of Geophysical Research, v. 107, doi: 10.1029/2001JB000471.

Lu, Z., Masterlark, T., Power, J., Dzurisin, D., and Wicks, J.C., 2002b, Subsidence at Kiska Volcano, western Aleutians, detected by satellite radar interferometry: Geophysical Research Letters, v. 29, doi: 10.1029/2002GL014948.

Lu, Z., Power, J.A., McConnell, V.S., Wicks, J.C., and Dzurisin, D, 2002c, Preeruptive inflation and surface interferometric coherence characteristics revealed by satellite radar interferometry at Makushin Volcano, Alaska: 1993-2000: Journal of Geophysical Research, v. 107, doi 10.1029/2001JB000970.

Lu, Z., Wicks, J.C., Dzurisin, D., Power, J., Thatcher, W., and Masterlark, T., 2003a, Interferometric synthetic aperture radar studies of Alaska volcanoes: Earth Observation Magazine, v. 12, p. 8-18.

Lu, Z., Masterlark, T., Dzurisin, D., Rykhus, R., and Wicks, J.C., 2003b, Magma supply dynamics at Westdahl volcano, Alaska, modeled from satellite radar interferometry: 
Journal of Geophysical Research, v. 108, doi: 10.1029/ 2002JB002311.

Mann, D., and Freymueller, J.T., 2003, Volcanic and tectonic deformation on Unimak Island in the Aleutian Arc, Alaska: Journal of Geophysical Research, v. 108, doi: 10.1029/ 2002JB001925.

Mann, D., Freymueller, J., and Lu, Z., 2002, Deformation as sociated with the 1997 eruption of Okmok volcano, Alaska: Journal of Geophysical Research, v. 107, doi: 10.1029/ 2001JB000163

Massonnet, D., and Feigl, K., 1998, Radar interferometry and its application to changes in the Earth's surface: Reviews in Geophysics, v. 36, p. 441-500, doi: 10.1029/ 97RG03139.

Massonnet, D., Briole, P., and Arnaud, A., 1995, Deflation of Mount Etna monitored by spaceborne radar interferometry: Nature, v. 375, p. 567-570, doi: 10.1038/375567A0.

Masterlark, T., and Lu, Z., 2004, Transient volcano deformation sources imaged with interferometric synthetic aperture radar: Application to Seguam Island, Alaska: Journal of Geophysical Research, v. 109, doi: 10.1029/2003JB002568.

Matthews, S.J., Gardeweg, M.C., and Sparks, R.S.J., 1997, The 1984 to 1996 cyclic activity of Lascar Volcano, northern Chile: Cycles of dome growth, dome subsidence, and explosive eruptions: Bulletin of Volcanology, v. 59, p. 72-82, doi: $10.1007 / \mathrm{S} 004450050176$.

McNutt, S.R., and Pritchard, M.E., 2003, Seismic and geodetic unrest at Uturuncu volcano, Bolivia (abstract): Eos (Transactions, American Geophysical Union), v. 84, p. 875.

Newhall, C.G., and Dzurisin, D., 1988, Historical unrest at large calderas of the world: USGS Bulletin, v. 1855, p. 1108.

Nishimura, T., Fujiwara, S., Murakami, M., Tobita, M. Nakagawa, H., Sagiya, T., and Tada, T., 2001, The M6.1 earthquake triggered by volcanic inflation of Iwate volcano, northern Japan, observed by satellite radar interferometry: Geophysical Research Letters, v. 28, p. 635-638, doi: 10.1029/2000GL012022.
Pritchard, M.E., 2003, Recent crustal deformation in westcentral South America [Ph.D thesis]: Pasadena, California, California Institute of Technology, http://etd.caltech.edu/etd/ available/etd06022003-105512/.

Pritchard, M.E., and Simons, M., 2002, A satellite geodetic survey of large-scale deformation of volcanic centres in the central Andes: Nature, v. 418, p. 167-171, doi: 10.1038/ NATURE00872.

Pritchard, M.E., and Simons, M., 2004, An InSAR-based survey of volcanic deformation in the central Andes: Geochemistry Geophysics Geosystems, v. 5, doi: 10.1029/ 2003GC000610.

Pritchard, M.E., Simons, M., Rosen, P., Hensley, S., and Webb, F., 2002, Co-seismic slip from the 1995 July 30 $M_{w}=8.1$ Antofagasta, Chile, earthquake as constrained by InSAR and GPS observations: Geophysical Journal International, v. 150, p. 362-376, doi: 10.1046/J.1365246X.2002.01661.X

Rosen, P.A., Hensley, S., Zebker, H.A., Webb, F.H., and Fielding, E.J., 1996, Surface deformation and coherence measurements of Kilauea Volcano, Hawaii, from SIR-C radar interferometry: Journal of Geophysical Research, v. 101, p. 23,109-23,125, doi: 10.1029/96JE01459.

Rosen, P.A., Hensley, S., Joughin, I.R., Li, F.K., Madsen, S.N., Rodriguez, E., and Goldstein, R.M., 2000, Synthetic Aperture Radar Interferometry: Proceedings of the IEEE, v. 88 , p. 333-382, doi: $10.1109 / 5.838084$

Rosen, P.A., Hensley, S., Peltzer, G., and Simons, M., 2004 Updated Repeat Orbit Interferometry Package released: Eo (Transactions, American Geophysical Union), v. 85, p. 47.

Simkin, T., and Siebert, L., 1984, Explosive eruptions in space and time: Durations, intervals and a comparison of the world's active volcanic belts, in Explosive volcanism: Inception, evolution and hazards: Washington, D.C., National Academy Press, Studies in Geophysics, p. 110-121.

Smithsonian Institution, 2004, Global volcanism report, http://www.volcano.si.edu (accessed 27 May 2004).
Solomon, S.C., Baker, V.R., Bloxham, J., Booth, J., Donnellan, A., Elachi, C., Evans, D., Rignot, E., Burbank, D., Chao, B.F., Chave, A., Gillespie, A., Herring, T., Jeanloz, R., LaBrecque, J., Minster, B., Pitman, I.W.C., Simons, M., Turcotte, D.L., and Zoback, M.L.C., 2003, Plan for living on a restless planet sets NASA's solid earth agenda: Eos (Transactions, American Geophysical Union), v. 84, p. 485.

Waltham, T., 2001, A guide to the volcanoes of southern Kamchatka, Russia: Proceedings of the Geologists Association, v. 112, p. 67-78.

Wessel, P., and Smith, W.H.F., 1998, New, improved version of Generic Mapping Tools released: Eos (Transactions, American Geophysical Union), v. 79, p. 579.

Wicks, C.W., Jr, Dzurisin, D., Ingebritsen, S., Thatcher, W. Lu, Z., and Iverson, J., 2002, Magmatic activity beneath the quiescent Three Sisters volcanic center, central Oregon Cascade Range, USA: Geophysical Research Letters, v. 29, doi: 10.1029/2001GL014205.

Zebker, H.A., and Villasenor, J., 1992, Decorrelation in interferometric radar echoes: IEEE Transactions on Geoscience and Remote Sensing, v. 30, p. 950-959, doi: 10.1109/ 36.175330 .

Zebker, H.A., Amelung, F., and Jonsson, S., 2000, Remote sensing of volcano surface and internal processes usin radar interferometry, in Mouginis-Mark, P.J., Crisp, J.A and Fink, J.H., eds., Remote sensing of active volcanism: Washington, D.C., American Geophysical Union, Geophysical Monograph 116, p. 179-205.

Zellmer, G.F., Sparks, R.S.J., Hawkesworth, C.J., and Wiedenbeck, M., 2003, Magma emplacement and remobilization timescales beneath Montserrat: Insights from $\mathrm{Sr}$ and $\mathrm{Ba}$ zonation in plagioclase phenocrysts: Journal of Petrology, v. 44, p. 1413-1431, doi: 10.1093/PETROLOGY/ 44.8.1413.

Manuscript submitted January 13, 2004; revised manuscript submitted May 5 , 2004; accepted May 27, 2004 